\title{
РЕАЛІЗАЦІЯ ОСВІТНЬОГО ПРОЦЕСУ В СУЧАСНІЙ ВІТЧИЗНЯНІЙ МАЛОКОМПЛЕКТНІЙ ШКОЛІ: ОСНОВНІ ПЕРЕВАГИ ТА НЕДОЛІКИ
}

У статті визначено, що вітчизняні малокомплектні школи сьогодні знаходяться в стані інтенсивної реконструкиії, причому рімення стосовно подальшої долі вітчизняних малокомплектних шкіл мають прийматися тільки на основі широкого публічного обговорення порушеної проблеми на основі врахування основних позитивних та негативних аспектів навчання учнів у иих школах.

Мета статі: визначити й проаналізувати основні переваги й недоліки реалізації освітнього процесу у вітчизняній малокомплектній школі. У процесі наукового пошуку використано загальнонаукові (аналіз, порівняння, узагальнення) методи з метою опрацювання наукової літератури 3 порушеної проблеми; спостереження, бесіди, анкетування учителів та батьків учнів малокомплектних шкіл із метою уточнення основних переваг та проблем у роботі цих закладів.

Як установлено в прочесі наукового пошуку, основними перевагами роботи малокомплектних шкіл є такі: наявність сприятливих передумов для реалізації індивідуальної освітньої траєкторії кожного учня; здійснення вчителем систематичного контролю навчальних досягнень школярів та внесення своєчасних коректив у їхню навчальну діяльність; можливість організувати конструктивну взаємодію між учнями різного віку, забезпечити їхній дієвий взаємовплив один на одного; створення доброзичливої «сімейної» атмосфери на заняттях, розбудова вчителем довірчих партнерських відносин зі школярами; організація інтенсивного спілкування педагога з кожним учнем; можливість своєчасної діагностики причин появи у школярів утруднень у навчанні та помилок під час виконання завдань. Серед основних недоліків реалізаиії освітнього процесу в зазначених школах слід відзначити: невисоку якість освіти, відсутність сучасного матеріально-технічного забезпечення освітнього процесу, брак висококваліфікованих учителів тощьо.

Ключові слова: малокомплектна школа, опорна школа, переваги, недоліки, освітній процес.

Tkachova N. O. The implementation of the educational process in a modern domestic small-scale school: basic advantages and disadvantages. It was 
defined in the article that domestic small-scale schools are in a state of intense reconstruction now, and the further fate decisions of domestic small-scale schools should be made only on the basis of a broad public discussion of the problem raised, based on the main positive and negative aspects of teaching students in these schools.

The purpose of the article: to identify and analyze the main advantages and disadvantages of the implementation of the educational process in the domestic small school. The scientific methods as (analysis, comparison, generalization) were used in the process of scientific search in order to study the scientific literature of the marked problem; observations, interviews, questionnaires of teachers and parents of students in small schools to clarify the main benefits and problems of these institutions.

As it was defined in the process of the scientific search, the main advantages of the work of small-scale schools are the following: the existence of favorable prerequisites for the implementation of an individual educational trajectory for each student; the implementation by the teacher of systematic control of students' educational achievements and making timely adjustments to their educational activities; the ability to organize the constructive interaction between the students of all ages, to provide effective interaction on each other; creating a welcoming "family" atmosphere in the classroom, building teacher-friendly partnerships with students; organization of intensive communication of the teacher with each student; the possibility of timely diagnosis of the students' causes with learning difficulties and mistakes during the tasks. The main typical shortcomings of the implementation of the educational process in these schools should be noted: the low quality of education, the absence of modern logistical support of the educational process, the shortage of highly qualified teachers, etc.

Keywords: small school, support school, advantages, disadvantages, educational process.

Вступ. В останні роки у вітчизняній педагогічній пресі точиться активна дискусія стосовно того, чи потрібно зберігати й розвивати в Україні сільські малокомплектні школи. Деякі вітчизняні вчені стверджують, що ці школи в останні роки втрачають свою значущість, а тому їх треба закрити. Прихильники протилежної точки зору вважають, що малокомплектні школи мають зберегти чільне місце серед інших закладів освіти, проте воднораз ці автори відзначають актуальну потребу в оптимізації освітнього процесу в них. Кожна з представлених вище наукових позицій, 3 одного боку, підкріплюється переконливими аргументами, а, з іншого, - має суттєві недоліки. 
Орієнтуючись на досвід вирішення зазначеної проблеми за кордоном, слід зазначити, що загалом у світі спостерігається тенденція до зменшення кількості малокомплектних шкіл. Проте уряди більшості країн дуже обережно ставляться до цієї проблеми та не форсують процес закриття малокомплектних шкіл, намагаючись приймати виважені рішення стосовно цих закладів. Адже в протилежному випадку прискориться міграція сільського населення в міста, а це негативно вплине на розвиток сільськогосподарської галузі в країні.

Очевидно, що в Україні теж мають прийматися грунтовні рішення стосовно визначення подальшої долі вітчизняних малокомплектних шкіл, а такі рішення можна виробити тільки на основі широкого публічного обговорення порушеної проблеми, до якого слід залучити провідних учених, учителів, економістів та фахівців в інших суміжних галузях. Отже, проблема вітчизняних малокомплектних шкіл вимагає сьогодні невідкладного й ефективного розв'язання.

Слід зауважити, що в останні роки проблема малокомплектних шкіл в Україні знаходиться в центрі уваги багатьох науковців. Так, специфіку реалізації освітнього процесу в малокомплектній школі розкрито в працях О. Біди, В. Мелешко, М. Нєустроєва, О. Савченко, Г. Тришнєвської та ін. Особливості формування навчальних умінь і навичок школярів в умовах вивчення ними окремих предметів у сільських малокомплектних школах висвітлено в працях Г. Кукли, А. Нікуліної, Г. Сосніної, Т. Чекмарьової та ін.

Історико-педагогічні аспекти організації навчальної діяльності в сільських малокомплектних школах у другій половині XX ст. проаналізовано в дисертаційних працях О. Пінського, Л. Прокопів та ін. Підготовці студентів до роботи в умовах сільської початкової школи присвячено наукові праці Н. Побірченко, Л. Присяжнюк та ін. Педагогічні умови підвищення професійної компетентності вчителів малокомплектних шкіл у системі післядипломної освіти визначено в наукових працях Л. Армейської, Л. Покроєвої, Н. Шацької та ін. 
Як засвідчує аналіз наукової літератури, учені зробили вагомий внесок у дослідження порушеної проблеми, проте в контексті сучасних реалій вона потребує подальшого вивчення. Зокрема, у процесі наукового пошуку визначено, що існує нагальна потреба в об'єктивному аналізі можливостей навчання школярів у сучасних малокомплектних школах на основі 3'ясування основних плюсів та мінусів цього процесу.

Мета та завдання: визначити й проаналізувати основні переваги й недоліки реалізації освітнього процесу у вітчизняній малокомплектній школі.

Методи дослідження. У процесі наукового пошуку використано загальнонаукові (аналіз, порівняння, узагальнення) методи для опрацювання наукової літератури 3 порушеної проблеми; спостереження, бесіди, анкетування учителів та батьків учнів малокомплектних шкіл 3 метою уточнення основних переваг та проблем у роботі зазначених закладів.

Результати. Як свідчить аналіз наукової літератури, прихильники ідеї укрупнення шкіл (Benovska, 2016; Stepanenko, 2016; Shubak, 2014) виступають за прискорення іiі реалізації на практиці. Вони посилаються на досвід забезпечення оптимізації шкільної мережі в таких розвинених країнах світу, як Австралія, Велика Британія, Норвегія, Швеція, США, Канада, Південна Корея, Португалія тощо. Ці автори пояснюють свою позицію наявністю в малокомплектній школі таких суттєвих вад:

1. Навчання учнів малокомплектної школи вимагає значно більших коштів, ніж школярів звичайних закладів загальної середньої освіти. Так, за даними аналізу Міністерства фінансів України, середній показник бюджетних витрат на 1 учня по Україні складає 14,9 тис. грн. на рік, а в малокомплектній школі - від 40 до 60 тис. Варто нагадати, що за останні роки кількість малокомплектних шкіл України загалом зменшилась, проте і сьогодні їх кількість складає понад 4,5 тисячі, із них - біля півтисячі початкових закладів освіти, де навчається менше 10 учнів. Очевидно, що утримання малокомплектних шкіл вимагає колосальних додаткових 
матеріальних витрат. Так, за даними Мінфіна, у 2017-2018 роках ця сума наблизилась до 2 млрд грн. (Kalashnikova, 2019).

2. Загалом в українських малокомплектних школах якість освіти $€$ достатньо низькою. Це насамперед пояснюється тим, що кожний педагог такої школи примушений звичайно викладати декілька навчальних предметів, у тому числі ті, які не пов’язані з отриманою ним спеціальністю. Така ситуація негативно впливає на навчальні досягнення школярів та на професійну мотивацію самих учителів.

3. Матеріально-технічне забезпечення сільських шкіл (особливо малокомплектних) не відповідає сучасним вимогам. Так, ці школи відрізняються слабою оснащеністю методичним і демонстраційним матеріалом, а близько $20 \%$ закладів навіть не мають комп'ютерів. Слід також нагадати, що на селі школи рідко мають спеціалізовані кабінети для вивчення окремих навчальних предметів, у третині закладів освіти немає навіть фізкультурного залу.

4. У малокомплектних школах бракує висококваліфікованих учителів. Низький рівень заробітної плати та нерозвинена інфраструктура в селі значно ускладнює можливість залучення таких фахівців до роботи в сільській школі.

5. Умови перебування в багатьох сільських школах взагалі шкідливі для здоров'я учнів. Зокрема, за даними Державної служби статистики України, майже чверть цих закладів не мають водогону, більше половини водогону з гарячою водою, у більшості шкіл туалет знаходиться на вулиці (Yak vriatuvaty silsku osvitu v Ukraini, 2016).

До визначених вище вад у роботі малокомплектних шкіл Г. Шубак додає ще такі типові недоліки:

1. Висока інтенсивність прямих комунікативних контактів педагога 3 кожним школярем спричиняє посилення психологічного тиску на нього, а використання вчителем одноманітних методів навчання провокує відчуття 
школярем втомлюваності, знижує його пізнавальний інтерес i навчальну мотивацію.

2. Вузьке коло спілкування учнів малокомплектної школи слабо сприяє оволодінню ними необхідними для життєдіяльності в суспільстві соціальними навичками.

3. Педагоги малокомплектних шкіл основну увагу, як правило, приділяють реалізації інформативної та стимулювальної функціям, а організуюча і контрольна функції набувають другорядного значення.

4. Реалізація вчителем системи неперервного контролю знижує значущість для школярів методів самоконтролю перебігу й результатів своєї навчальної діяльності.

5. У школах бракує сучасних навчально-методичних комплексів, методичних матеріалів самоосвітнього спрямування для учнів, а організація роботи тільки за одним підручником негативно впливає на результативність освітнього процесу.

6. Низькі навчальні досягнення школярів малокомплектної школи спричиняють появу значних труднощів у забезпеченні державних вимог до рівня освітньої підготовленості, а як наслідок - проблеми під час вступу випускників до закладів вищої освіти (Shubak, 2004).

Як відзначається в науковій літературі, здійснення освітнього процесу на базі великої опорної школи замість малокомплектного закладу освіти надає суттєві переваги всім учасникам педагогічної взаємодії. Так, учні отримують можливість здобути більш якісну освіту (а як наслідок - мають більші шанси на вступ після закінчення школи до закладів вищої освіти), обрати освітню програму та профіль навчання відповідно власних здібностей та інтересів, мати широке коло спілкування як необхідної передумови для успішної соціалізації, навчатися в приміщеннях, які відповідають існуючим санітарно-гігієнічним нормам, якісно харчуватися.

Педагоги опорних шкіл мають стабільне навантаження та викладають профільні для них предмети, а також отримують більш високу заробітну 
плату. Крім того, учителі великих шкіл можуть використовувати у своїй професійній діяльності сучасне матеріально-технічне оснащення освітнього процесу, а також отримують кращі можливості для підвищення рівня професійної компетентності. Варто також зауважити, що укрупнення сільських шкіл сприяє підвищенню доходів освітньої галузі, тобто є економічно вигідним для держави (Hrynevych, 2019; Stepanenko, 2016).

Зазначимо, що Міністерство освіти України визначило курс на поступове закриття малокомплектних шкіл у країні та переведення учнів для навчання у великі, добре оснащені в матеріально-технічному й ресурсному аспектах опорні заклади загальної середньої освіти. Зокрема, в Україні наразі функціонує вже 767 опорних шкіл. Протягом останніх років основні інвестиції вкладаються саме в інфраструктуру цих шкіл (Hrynevych, 2019).

Як визначено на основі аналізу праць прибічників збереження малокомплектних шкіл (Meleshko, 2002; Pobirchenko, 2004; Tevlin, 2004), ці школи такі мають такі основні переваги в роботі:

1. Наявність сприятливих передумов для розроблення й реалізації на практиці індивідуальної освітньої траєкторії для кожного учня.

2. Можливість здійснення систематичного контролю навчальних досягнень учнів та внесення своєчасних коректив у їхню навчальну діяльність.

3. Через малу кількість школярів педагог має змогу краще вивчити індивідуальні особливості й інтереси дітей та організувати педагогічну взаємодію з урахуванням цих особливостей.

4. Різновікові групи школярів дозволять організувати конструктивну взаємодію між учнями різного віку, їхній дієвий взаємовплив один на одного, що при правильній організації позитивно впливає на начальні досягнення всіх учасників освітнього процесу.

5. Створення доброзичливої «сімейної» атмосфери на заняттях, розбудова вчителем довірчих партнерських відносин зі школярами. 
6. Організація інтенсивного спілкування педагога 3 кожним школярем.

7. Можливість своєчасної діагностики причин появи у школярів утруднень у навчанні та помилок під час виконання завдань, на цій підставі внесення відповідних коректив у організацію освітнього процесу.

У науковій літературі також привертається увага до тих проблем, які виникають в Україні унаслідок знищення малокомплектних шкіл. Так, необдумана освітня політика провокує прискорення процесу руйнування й навіть знищення українських сіл, які традиційно були головним осередком унікальної національної культури українського народу. Крім того, ефективна робота школи значною мірою забезпечує підвищення загального культурного рівня мешканців сіла, сприяє успішному вирішенню проблеми закріплення молоді в сільській місцевості та демографічних проблем.

Тому недостатньо продуманий процес укрупнення сільської школи й ліквідації на цій основі малокомплектних закладів освіти може спровокувати виникнення значних проблем у галузі освіти та нанести невиправдану шкоду сільському населенню та самому селу як адміністративно-територіальній одиниці, прискорити руйнацію сільської інфраструктури (Meleshko, 2002; Pobirchenko, 2004; Tevlin, 2004).

У науковій літературі також визначаються інші негативні аспекти необгрунтованого прискорення процесу оптимізації шкільної мережі. Так, відсутність нормальних доріг, брак транспорту для доставки учнів до опорних шкіл, неналежний технічний стан наявних автобусів для перевезення учнів, наявність складних погодних умов восени та взимку для перевезення учнів значно загострює проблему їх доставки до опорних шкіл. Крім того, за результатами опитування вчителів та батьків учнів малокомплектних шкіл, запропонований для навчання дітей опорний заклад освіти, часто знаходиться на відстані понад 10 км від місця їхнього проживання, тому нерідкими є випадки, коли школярі взагалі не можуть потрапити до школи. 
Суттєвим негативним аспектом сучасної модернізації системи навчання сільських дітей є також відсутність: чітких державних стандартів, теоретично обгрунтованої й апробованої концепції організації освітнього процесу в опорній школі, моделі поступового переходу від малокомплектної до укрупненої школи, положення про функціонування великої опорної школи в селі, що значно ускладнює й гальмує процес реорганізації малокомплектних шкіл (Stepanenko, 2016).

Варто також зауважити, що для успішного переходу від малокомплектної до опорної школи в селі потрібні значні матеріальні кошти для відновлення проекту «Шкільний автобус», ремонту й побудови нових доріг, по яким можна буде добратися до опорних шкіл, закупівлі нового транспорту та ремонту старих автобусів для дітей, створення автобусних шкільних парків. Брак цих коштів ставить можливість окресленого переходу сільських дітей до навчання в опорній школі взагалі під загрозу (Stepanenko, 2016).

Значною проблемою для сільської школи $\epsilon$ також пошук кваліфікованих педагогів, адже небагато висококомпетентних професіоналів погодиться працювати в сільській школі навіть районного значення. Ускладнює ситуацію і той факт, що заклади вищої педагогічної освіти ще навіть не розпочали підготовку вчителів до роботи в опорних школах, діяльність у яких має свою специфіку, відсутність необхідних для здійснення такої підготовки нових навчальних програм та планів.

Варто також зазначити, що в процесі сучасного реформування сільської школи загострюється багато проблем не тільки об'єктивного, але й суб’єктивного характеру. Так, батьки проявляють слабку обізнаність щодо доречності закриття малокомплектних шкіл та доцільності навчання своїх дітей у краще пристосованих та матеріально-технічно обладнаних опорних школах. Багато учителів теж мають слабку мотивацію щодо переведення працювати у віддалену школу, адже практично всі з них мають присадибне господарство, а щоденні переїзди до опорної школи, зазвичай, займають 
багато часу. Крім того, педагоги малокомплектних шкіл постійно відчувають ризик скорочення педагогічних кадрів, зменшення штату непедагогічних працівників, зниження статусу шкіл-філій з 1-III до II чи навіть I рівня, що негативно вплине на заробітну плату людей (Meleshko, 2002; Pobirchenko, 2004; Stepanenko, 2016).

Не сприяє зацікавленості сільського населення у створенні опорних шкіл також політична та економічна нестабільність у країні, що не гарантує отримання опорними школами достатніх матеріальних та інших ресурсів. Ставлення сільського населення до ідеї опорних шкіл погіршують також авторитарні дії представників органів різних гілок влади, які приймають рішення про закриття малокомплектних шкіл без попереднього обговорення цього питання з батьками учнів. Наслідком цього стали випадки, коли мешканці сіл оголошували страйки та відмовлялись возити своїх дітей у нові школи.

Обговорення. Проведене дослідження підтверджує висновки вітчизняних і зарубіжних учених щодо подальшої долі малокомплектних шкіл в Україні. Рішення щодо діяльності зазначених шкіл мають прийматися тільки на основі широкого публічного обговорення порушеної проблеми, врахування основних позитивних та негативних аспектів навчання учнів у цих закладах.

Висновки. На підставі викладеного можна підсумувати, що проблема реформування сільських малокомплектних шкіл та створення опорних закладів загальної середньої освіти є дуже складною. Тому пошук варіантів вирішення цієї проблеми вимагає врахування та детального аналізу всіх ii основних аспектів. Як доведено, навчання дітей у малокомплектних школах чи опорних школах має свої позитивні й негативні аспекти. Тому рішення про закриття чи збереження кожної малокомплектної школи має прийматися з урахуванням іiі розташування, відстані від найближчої опорної школи, наявності доріг та транспорту для доставки дітей, а головне - можливостей цього закладу забезпечити учням гідну освіту. 
У цьому плані $є$ багато резервів, які сьогодні недостатньо використовуються, а саме: створення спеціальних програм для навчання учнів в умовах малокомплектних шкіл, здійснення професійної підготовки майбутніх учителів до роботи в цих закладах та забезпечення підвищення професійного рівня працюючих там педагогів, активне використання в освітньому процесі сучасних інформаційно-комунікативних технологій тощо. Адже важливо враховувати, що школа сьогодні залишається основним освітнім і культурним центром, стабілізуючим чинником села. Тому від подальшої долі школи значною мірою залежить майбутнє його мешканців. Подальші наукові розвідки планується присвятити вивченню досвіду роботи малокомплектних шкіл у провідних країнах світу.

\section{ЛІТЕРАТУРА:}

Беновська Л. Я. Формування опорних шкіл в умовах реформування місцевого самоврядування. Соціально-економічні проблеми сучасного періоду України. 2016. Вип. 2. С. 32-37.

Гриневич Л. Опорні школи - це не лише краща якість освіти для дітей, а й вища зарплата для вчителя [Електронний ресурс]. Режим доступу : https://mon.gov.ua/ua/news/oporni-shkoli-ce-ne-lishe-krasha-yakist-osviti-dlya-ditej-jvisha-zarplata-dlya-vchitelya-liliya-grinevich.

Калашнікова О. Оптимізація шкіл - не вирок : як знизити градус напруги [Електронний pecypc]. Режим доступу : https://life.pravda.com.ua/columns/2019/04/15/236556.

Мелешко В. В. Управління малокомплектними початковими школами різної структури : автореф. дис. ... канд. пед. наук за спец. 13.00.01; Ін-т педагогіки АПН України. К., 2002. $22 \mathrm{c}$.

Побірченко Н. С. Малокомплектна школа: сучасний вимір. Психолого-педагогічні проблеми сільської школи : зб. наук. праць Уман. держ. пед. ун-ту імені Павла Тичини. Умань : Уман. держ. пед. ун-т імені Павла Тичини, 2004. Вип. 10. 207 с.

Степаненко М. І. Укрупнення шкіл у XXI столітті : переваги і втрати / М. І. Степаненко // ПостМетодика. - 2016. - № 2 (125). - С. 35-40.

Супрунова І. В., Зеленіна О. О. Оптимізація кількості шкіл в Україні : регіональний аспект. Проблеми теорії та методології бухгалтерського обліку, контролю $i$ аналізу. 2012. Вип. 1 (22). С. 366-370.

Тевлін Б. Л. Урок у малокомплектній школі. Психолого-педагогічні проблеми сільської школи : наук. зб. Умань : Уманський держ. пед. ун-т імені Павла Тичини, 2004. Вип. 9. С. 72-78.

Шубак Г. Специфіка організації процесу навчання в сільських малокомплектних школах різних типів і структур. Молодь і ринок. 2014. № 8. С. 108-114.

Як врятувати сільську освіту в Україні [Електронний ресурс]. Режим доступу : https://konkurent.in.ua/publication/10191/ak-vryatuvati-silsku-osvitu-v-ukrayini.

\section{REFERENCES:}

Benovska, L. (2016). Formuvannia opornykh shkil v umovakh reformuvannia mistsevoho samovriaduvannia [The formation of support schools in the context of local government 
reform]. Socialno-ekonomichni problemy suchasnogo periodu Ukrayiny. 2. $32-37$ (in Ukranian).

Hrynevych, L. (n. d.) Oporni shkoly - tse ne lyshe krashcha yakist osvity dlia ditei, a i vyshcha zarplata dlia vchytelia [Support schools are not only better quality education for children, but also higher pay for teachers]. Retrieved from https://mon.gov.ua/ua/news/opornishkoli-ce-ne-lishe-krasha-yakist-osviti-dlya-ditej-j-visha-zarplata-dlya-vchitelya-liliyagrinevich (in Ukranian).

Kalashnikova, O. (n. d.) Optymizatsiia shkil - ne vyrok : yak znyzyty hradus naprugy [The school optimization is not a verdict: how to reduce the degree of stress]. Retrieved from https://life.pravda.com.ua/columns/2019/04/15/236556 (in Ukranian).

Meleshko, V. (2002). Upravlinnia malokomplektnymy pochatkovymy shkolamy riznoi struktury [Management of small-scale elementary schools of different structure] (Abstract of candidate's thesis, National Academy of Educational Sciences of Ukraine). Kyiv, Ukraine (in Ukranian).

Pobirchenko, N. (2004). Malokomplektna shkola : suchasnyi vymir. [A small-scale school: modern udders]. Psykholoho-pedahohichni problemy silskoi shkoly, 10, 207. (in Ukranian).

Shubak, H. (2014). Spetsyfika organizatsii protsesu navchannia v silskykh malokomplektnykh shkolakh riznykh typiv i struktur [The specifics of the organization of the learning process in rural small schools of different types and structures]. Molod i rynok, 8, 108114 (in Ukranian).

Stepanenko, M. (2016). Ukrupnennia shkil u XXI stolitti : perevahy i vtraty [School Enlargement in the 21st Century: Benefits and Losses] // PostMetodyka, 2 (125), 35-40 (in Ukranian).

Suprunova, I. (2012). Optymizatsiia kilkosti shkil v Ukraini : rehionalnyi aspekt [The optimizing of the number of schools in Ukraine: a regional dimension]. Problemy teorii ta metodolohii bukhhalterskoho obliku, kontrolyiu i analizu, 1 (22), 366-370 (in Ukranian).

Tevlin, B. (2004). Urok u malokomplektnii shkoli. [A lesson in the small-scale school]. Psyxologo-pedagogichni problemy silskoyi shkoly, 9, 72-78 (in Ukranian).

Yak vriatuvaty silsku osvitu v Ukraini. (n. d.) [How to save the rural education in Ukraine]. Retrieved from https://konkurent.in.ua/publication/10191/ak-vryatuvati-silsku-osvitu-vukrayini.

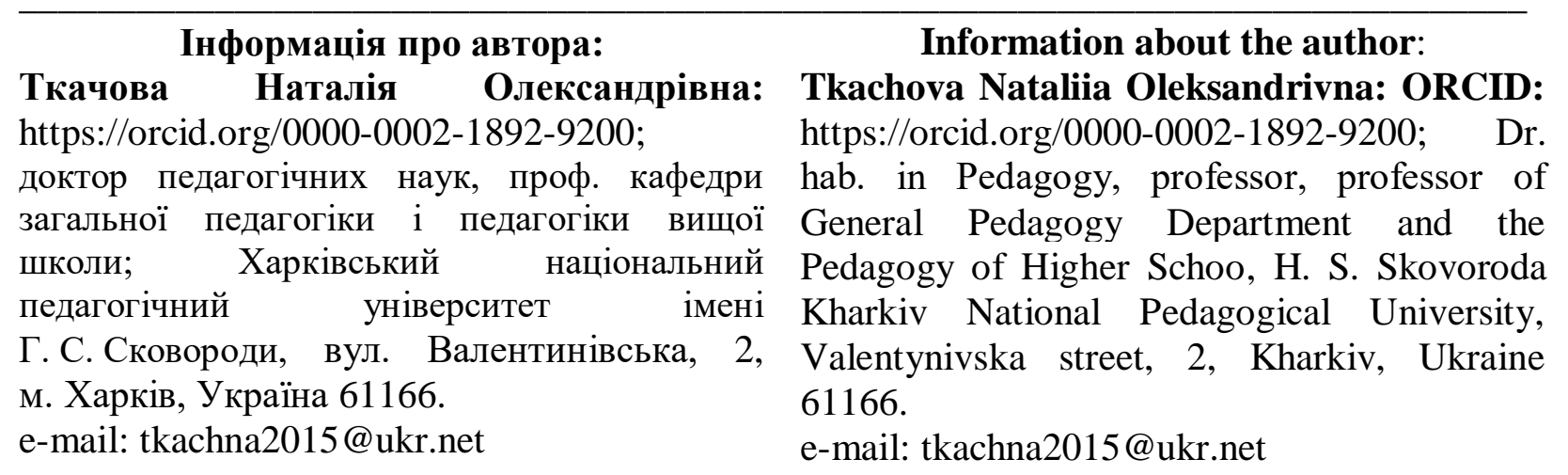

Цитуйте цю статтю як: Ткачова Н.О. Реалізація освітнього процесу в сучасній вітчизняній малокомплектній школі: основні переваги та недоліки. Теорія та методика навчання та виховання. 2019. № 46. C. 143-154. DOI: 10.34142/23128046.2019.46.11

Дата надходження статті до редакції: 15.05.2019

Стаття прийнята до друку: 30.05.2019 